\title{
Wolbachia infection prevalence as common insects' endosymbiont in the rural area of Yogyakarta, Indonesia
}

\author{
DIAN ARUNI KUMALAWATI ${ }^{1,2}$, ENDAH SUPRIYATI ${ }^{1}$, MIFTA PRATIWI RACHMAN ${ }^{1,3}$, \\ RISKY OKTRIANI ${ }^{1,4}$, IRIANTI KURNIASARI ${ }^{1,5}$, DAMIANA SAPTA CANDRASARI ${ }^{1,6}$, LISNA HIDAYATI ${ }^{1,7}$, \\ ANASTASIA EVI HANDAYANINGSIH ${ }^{1,8}$, VIERA CRISTALIA PROBOWATI ${ }^{1}$, BUDI ARIANTO ${ }^{1}$, \\ DWI SATRIA WARDANA ${ }^{1}$, NIDA BUDIWATI PRAMUKO ${ }^{1}$, ADI UTARINI ${ }^{1,9}$, WARSITO TANTOWIJOYO ${ }^{1,}$ \\ EGGI ARGUNI ${ }^{1,10, \bullet}$ \\ ${ }^{1}$ World Mosquito Program Yogyakarta, Centre of Tropical Medicine, Faculty of Medicine, Public Health and Nursing, Universitas Gadjah Mada. \\ Jl. Farmako, Sleman 55281, Yogyakarta, Indonesia \\ ${ }_{2}^{2}$ Department of Biology, Faculty of Science and Technology, Universitas Islam Negeri Sunan Kalijaga. Jl. Laksda Adisucipto, Sleman 55281, \\ Yogyakarta, Indonesia \\ ${ }^{3}$ Department of Biotechnology, Universitas Teknologi Sumbawa. Jl. Raya Olat Maras, Moyo Hulu, Sumbawa 84371, Nusa Tenggara Barat, Indonesia \\ ${ }^{4}$ Department of Biochemistry, Faculty of Medicine, Public Health and Nursing, Universitas Gadjah Mada. Jl. Farmako, Sleman 55281, Yogyakarta, \\ Indonesia \\ ${ }^{5}$ Department of Biotechnology, Sustainable Agricultural Extension Program, Politeknik Pembangunan Pertanian Malang. Jl. Dr. Cipto 144a, Malang \\ 65215, East Java, Indonesia \\ ${ }^{6}$ Faculty of Pharmacy, Universitas Sanata Dharma. Jl. Paingan, Maguwoharjo, Sleman 55281, Yogyakarta, Indonesia \\ ${ }^{7}$ Department of Tropical Biology, Faculty of Biology, Universitas Gadjah Mada. Jl. Teknika Selatan, Sleman 55281, Yogyakarta, Indonesia \\ ${ }^{8}$ Department of Internal Medicine, Faculty of Medicine, Public Health and Nursing, Universitas Gadjah Mada, J1. Farmako, Sleman 55281, Yogyakarta, \\ Indonesia \\ ${ }^{9}$ Department of Health Policy and Management, Faculty of Medicine, Public Health and Nursing, Universitas Gadjah Mada, Jl. Farmako, Sleman 55281, \\ Yogyakarta, Indonesia \\ ${ }^{10}$ Department of Pediatrics, Faculty of Medicine, Public Health and Nursing, Universitas Gadjah Mada, Jl. Farmako, Sleman 55281, Yogyakarta, \\ Indonesia. Tel.: +62-274-560300, "email: eggiarguni@ugm.ac.id
}

Manuscript received: 7 September 2020. Revision accepted: 16 November 2020.

\begin{abstract}
Kumalawati DA, Supriyati E, Rachman MP. Oktriani R, Kurniasari I, Candrasari DS, Hidayati L, Handayaningsih AE, Probowati VC, Arianto B, Wardana DS, Pramuko NB, Utari A, Tantowijoyo W, Arguni E. 2020. Wolbachia infection prevalence as common insects' endosymbiont in the rural area of Yogyakarta, Indonesia. Biodiversitas 21: 5608-5614. Control for mosquito-borne diseases such as dengue and chikungunya using vectors is urgently required. The World Mosquito Program, a multinational collaborative research program, is currently studying for the ability of Wolbachia-infected Aedes aegypti to control dengue. Community concerns on Wolbachia's natural existence in their surrounding living area. This study presents the field study of Wolbachia pipientis in insects commonly found in rural daily life. W. pipientis is an endosymbiotic bacterium commonly found in arthropods. Insects were collected from five villages in Sleman and Bantul District, Yogyakarta Province, Indonesia, from July to December 2012 and screened for Wolbachia infection using PCR. One hundred insects, including butterflies, moths, mosquitoes, flies, were collected. The results indicated that $44.9 \%$ of identified insect species were positive for Wolbachia pipientis, which support the existing data from other regions on the spread of Wolbachia infection in insects.
\end{abstract}

Keywords: Arthropods, bacteria, endosymbiotic, insects, Wolbachia pipientis

\section{INTRODUCTION}

Dengue infection is a viral disease estimated to cause a high public health burden in the world (Bhatt et al. 2013; Indriani et al. 2018). This infection is primarily transmitted by Aedes aegypti. The technology proposed by the World Mosquito Program Yogyakarta in 2012 is to use artificially infected Wolbachia bacteria to Aedes aegypti as biological dengue control in open field trials in Yogyakarta, Indonesia as a collaborator with Australia, Vietnam, and Brazil. Yogyakarta Province is one of the ten most prevalent provinces of dengue cases reported yearly (Kementrian Kesehatan RI 2010). Since community acceptability is very crucial to this trial, one of the community engagement strategies was to address their concerns about this new technology. One of the initial problems that emerged from the research site community was: what is Wolbachia? Is it a foreign biological creature or one commonly found in our daily lives? (WMP 2015, data not shown). The aim of this study was to respond to the concerns of the community.

Wolbachia pipientis is currently a large and diverse bacterial species within the Alpha-proteobacteria. They are most closely related to Rickettsia, Anaplasma, and Ehrlichia. However, unlike their relatives, Wolbachia only infects arthropods and some nematodes and has never been found in invertebrates. Wolbachia strains in supergroups A \& B only infect insects. They are very distantly related to those infecting nematodes, which belong to supergroups $\mathrm{C}$ $\& \mathrm{D}$ and are currently being considered for reclassification into separate species (Pfarr et al. 2007). Wolbachia 
pipientis was initially discovered in 1924 in the ovaries of the mosquito Culex pipiens. In the initial discovery, it was screened as a potential new human pathogen. However, tests involving its introduction into mice showed it is nonpathogenic and a common symbiont of mosquitoes. Wolbachia does not produce spores nor contain plasmids. There are several different types (strains) of Wolbachia, usually associated with a single host species (Werren et al. 2008). In recent decades, screening of insect species using PCR amplification and DNA sequencing has revealed that Wolbachia is estimated to infect between $20-76 \%$ of insect species worldwide (Jeyaprakash and Hoy 2000; Stevens et al. 2001; Weinert et al. 2007; Werren and Windsor 2000; Werren et al. 1995). It suggests that a more likely figure of $75 \%$ of all arthropod species are infected. They do not infect humans or any other vertebrates (Bandi et al. 2001; Bouchon et al. 1998; Breeuwer and Jacobs 1996; Rowley et al. 2004; Taylor and Hoerauf 1999; Woo Oh et al. 2000). Aedes aegypti does not naturally harbor Wolbachia (Ruang-Areerate and Kittayapong 2006), although many other species of mosquito are known to be infected (Rasgon and Scott 2004; Tsai et al. 2004).

Wolbachia strains are typically $0.5-1 \mu \mathrm{m}$ in size and live as highly specialized obligate endosymbionts in the cytoplasm of the host cells. Wolbachia strains are neither infectious nor can be transmitted from insect to insect as a pathogen. Instead, they are passed from parent to offspring through the insect eggs. Artificial transfer across different species is complicated and has only been obtained in the laboratory following microinjection of purified Wolbachia into the insects. Studies in Indonesia found that Wolbachia infects butterflies, moths, mosquitoes, and ants (Lohman et al. 2008; Narita et al. 2007; Wenseleers et al. 1998).
Yogyakarta Province is located in the south-central of Java Island (Figure 1), is one of the most populous provinces in Indonesia, consisting of five districts. The total population of Sleman District is $1,128,943$, with an area of 574.82 square kilometers. The total population of Bantul District is 934,674; with an area of 506.85 square kilometers. The results of the study could support existing data that Wolbachia is common bacteria that naturally infect common insects around human settlements in Yogyakarta.

\section{MATERIALS AND METHODS}

\section{Sampling location and time}

The research was conducted in five study sites in Yogyakarta Province, Indonesia, i.e.: 2 villages in Bantul District (Jomblangan and Singosaren); and three villages in Sleman District (Kalitirto, Nogotirto, and Kronggahan) (Figure 1). Samples were collected from July to December 2012.

\section{Sample collection}

We used purposive random sampling consisting of three collection methods, which are direct catch (using bananas as bait), sweep-net, and light trap for nocturnal insects. The samples were indoor, outdoor, and agricultural insects. Samples were sent to taxonomists at the Faculty of Biology, Universitas Gadjah Mada, Yogyakarta, Indonesia for species identification. One to five samples per species were collected for diagnostic assessment. The samples were stored in $70 \%$ ethanol and kept under $-20{ }^{\circ} \mathrm{C}$ for further analysis.

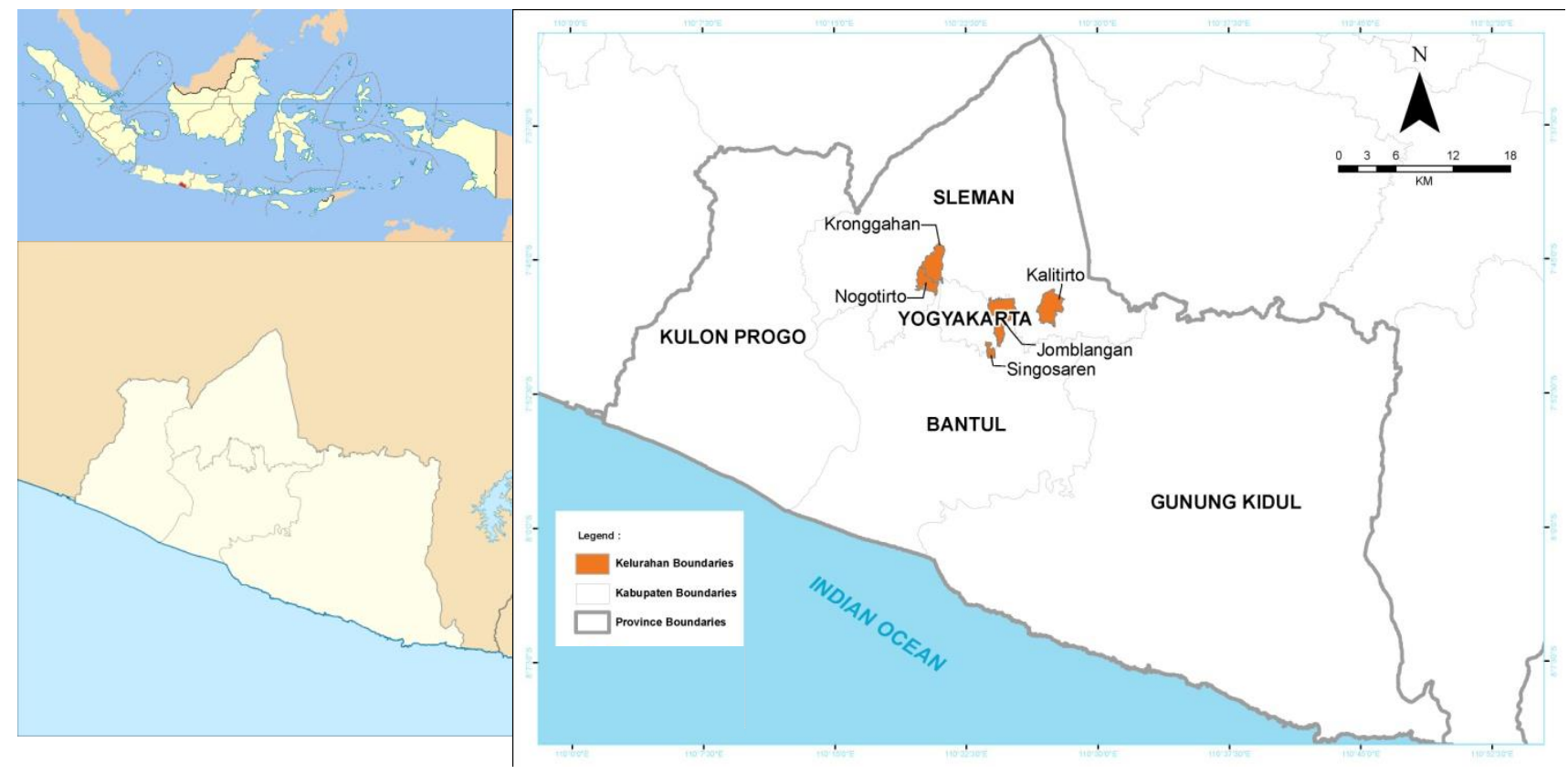

Figure 1. Research site in Yogyakarta Province, Indonesia (left) and sampling areas (right) 


\section{Wolbachia detection by polymerase chain reaction (PCR) and data analysis}

The thorax and abdomen from each individual (or the whole body for small insects) were taken for the extraction process. DNA extraction was performed using a commercial DNA isolation kit (Genejet Genomic DNA Purification Kit, Thermo Scientific). wMel+ Aedes aegypti was used as a positive control assay. The extraction procedure followed the Thermo Scientific Company's procedure with modification. The quality of genomic DNA extracted from samples was checked by PCR targeting butterfly DNA using arthropod-specific $28 \mathrm{~S}$ rRNA primers, amplified as previously described (Werren et al. 1995).

The PCR to detect Wolbachia was performed by Maxima Hot Start Green PCR Master Mix (2X) (Thermo Scientific) using Wolbachia general primers against the Wolbachia surface protein gene (wsp gene) (Braig et al., 1998). These primers generate a $610 \mathrm{bp}$ product. The primers were diluted to obtain the appropriate and optimum concentration for the PCR procedure, which was $10 \mu \mathrm{M}$ for wsp primers.

\section{Primer 81F: 5'-TGGTCCAATAAGTGATGAAGAAAC-3' Primer 691R: 5'-AAAAATTAAACGCTACTCCA-3'}

The total volume of the PCR mix was $20 \mu \mathrm{L}$. PCR reactions were run at $95^{\circ} \mathrm{C}$ for $3 \mathrm{~min}$ followed by 35 cycles of $95^{\circ} \mathrm{C}$ for $30 \mathrm{~s}, 50^{\circ} \mathrm{C}$ for $30 \mathrm{~s}$, and $72^{\circ} \mathrm{C}$ for $1 \mathrm{~min}$ using a thermal cycler (BioRad C-1000 Touch). Horizontal agarose gel electrophoresis apparatus (Mupid® Ex-U) was used to perform DNA analysis. Four uL of 6x loading dye was added to the PCR tube and run in a $2 \%$ agarose gel containing GelRed Nucleic Acid Stain. The PCR product should be about 610bp in size compared to the DNA
Ladder (100bp Ladder Thermo Scientific). The band was visualized using Geldoc Documentation System (Protein Simple). The $610 \mathrm{bp}$ band was used to determine the presence of Wolbachia. The percentage of Wolbachia in insects was counted with the following formula :

Total number of insects species positive for Wolbachia X 100\% Total number of identified insects species

\section{Ethics approval}

This study was part of the World Mosquito Program (WMP) Yogyakarta (formerly known as the Eliminate Dengue Program) Phase 1. Ethical approval was obtained from the Medical and Health Research Ethics Committee, Faculty of Medicine, Public Health and Nursing Universitas Gadjah Mada, Indonesia (approval number $\mathrm{KE} / \mathrm{FK} / 01 / \mathrm{EC} / 2012$ )

\section{RESULTS AND DISCUSSIONS}

\section{Results}

From 100 collected insects, 49 species were identified from 8 different orders. Those were screened for Wolbachia infection, of which $44.9 \%$ were positive for the bacteria (Table 1). Wolbachia were found in each of the major orders, including Diptera, Coleoptera, and Lepidoptera, Hymenoptera, and Orthoptera. The order Lepidoptera has the highest distribution of Wolbachia (12 of 25 individuals). Figure 2 shows amplification of $610 \mathrm{bp}$ DNA fragment by using $81 \mathrm{~F}$ and $691 \mathrm{R}$ primers for wsp gene (figure represented examples of positive and negative samples of analyzed insects)

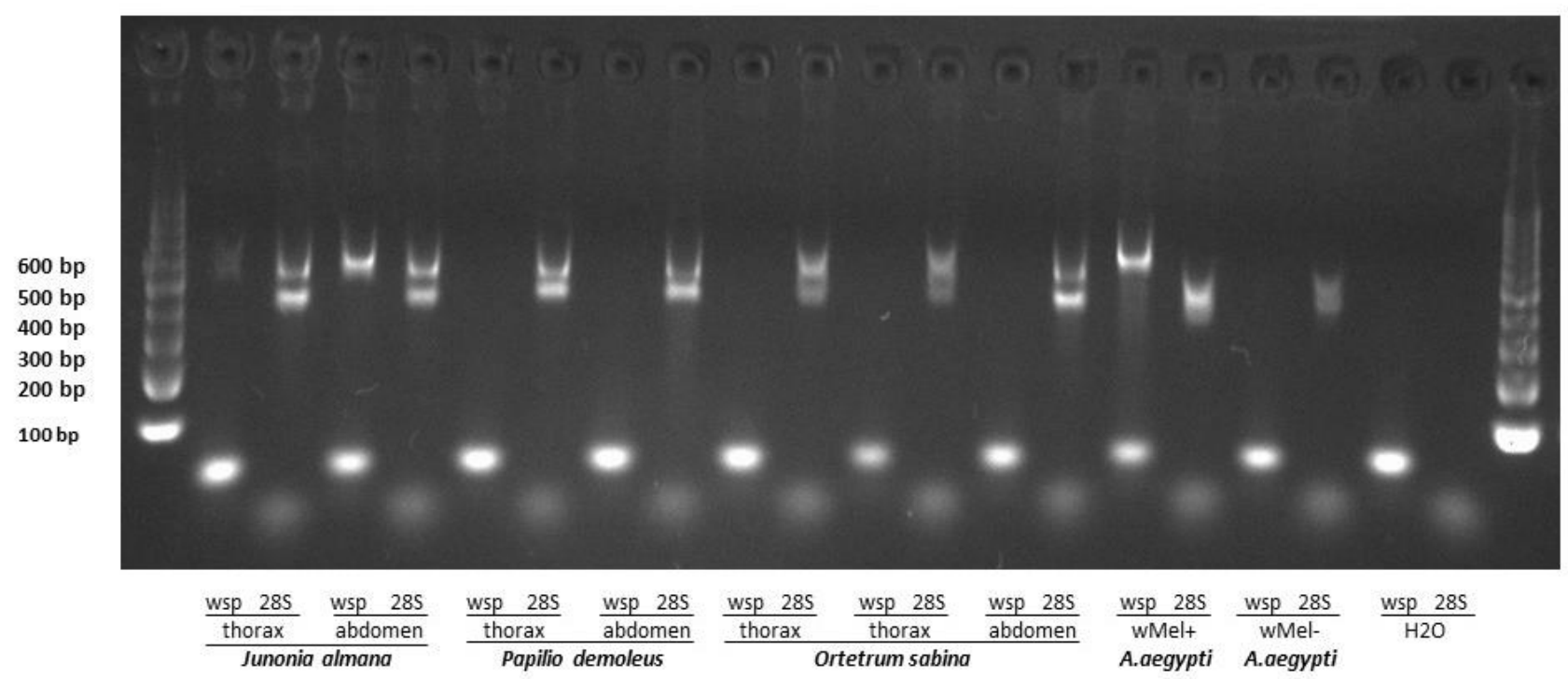

Figure 2. Amplification result of wsp primers set in Junonia almana, but not in Papilio demoleus and Orthetrum sabina. An amplification band of 28S rRNA was detected in all samples. wMel+ Aedes aegypti was a positive control, wMel- Aedes aegypti and $\mathrm{H}_{2} \mathrm{O}$ were negative control. 
Table 1. The presence of Wolbachia in collected insect samples (T: Thorax; A: Abdomen; WB: Whole Body)

\begin{tabular}{|c|c|c|c|c|}
\hline Order & Common name & Species & $\begin{array}{l}\text { Body part used for } \\
\text { DNA isolation }\end{array}$ & $\begin{array}{c}\text { Presence of } \\
\text { Wolbachia }\end{array}$ \\
\hline Blattodea & Cockroach & Periplaneta spp. & $\mathrm{T}, \mathrm{A}$ & Negative \\
\hline \multirow{4}{*}{ Coleoptera } & Ladybug & Henosepilachna sparsa & WB & Positive \\
\hline & Beetle & Aspidomorph amiliaris & WB & Negative \\
\hline & Beetle & Apoderus sp. & WB & Positive \\
\hline & Beetle & Coelophora reniplagiata & WB & Negative \\
\hline \multirow{4}{*}{ Diptera } & Beetle & Paederus sp. & WB & Negative \\
\hline & Flies & Drosophila melanogaster & WB & Positive \\
\hline & Mosquitoes & Aedes albopictus & WB & Positive \\
\hline & Mosquitoes & Aedes aegypti & WB & Negative \\
\hline Hemiptera & Ladybug & Leptocorisa acuta & WB & Negative \\
\hline \multirow[t]{6}{*}{ Hymenoptera } & Bees & Apis mellifera & $\mathrm{T}, \mathrm{A}$ & Positive \\
\hline & Wasp & Poliste sagitarius & $\mathrm{T}, \mathrm{A}$ & Negative \\
\hline & Wasp & Delta camponiforme & $\mathrm{T}, \mathrm{A}$ & Positive \\
\hline & Wasp & Sceliphron sp. & $\mathrm{T}, \mathrm{A}$ & Positive \\
\hline & Wasp & Vespa analis & $\mathrm{T}, \mathrm{A}$ & Negative \\
\hline & Wasp & Xylocopa confusa & $\mathrm{T}, \mathrm{A}$ & Negative \\
\hline \multirow[t]{23}{*}{ Lepidoptera } & Butterfly & Papilio memnon & $\mathrm{T}, \mathrm{A}$ & Positive \\
\hline & Butterfly & Catopsilia pomona & $\mathrm{T}, \mathrm{A}$ & Positive \\
\hline & Butterfly & Neptis hylas & WB & Positive \\
\hline & Butterfly & Mycalesis horsfieldi & $\mathrm{T}, \mathrm{A}$ & Positive \\
\hline & Butterfly & Eurema blanda & $\mathrm{T}, \mathrm{A}$ & Negative \\
\hline & Butterfly & Eurema candida & $\mathrm{T}, \mathrm{A}$ & Negative \\
\hline & Butterfly & Elymnia hypermnestra & $\mathrm{T}, \mathrm{A}$ & Positive \\
\hline & Butterfly & Elymnias nesaea & $\mathrm{T}, \mathrm{A}$ & Negative \\
\hline & Butterfly & Papilio polytes & $\mathrm{T}, \mathrm{A}$ & Positive \\
\hline & Butterfly & Delias hyparete & $\mathrm{T}, \mathrm{A}$ & Negative \\
\hline & Butterfly & Melanitis leda & $\mathrm{T}, \mathrm{A}$ & Positive \\
\hline & Butterfly & Junonia atlites & $\mathrm{T}, \mathrm{A}$ & Positive \\
\hline & Butterfly & Junonia almana & $\mathrm{T}, \mathrm{A}$ & Positive \\
\hline & Butterfly & Papilio demoleus & $\mathrm{T}, \mathrm{A}$ & Negative \\
\hline & Butterfly & Hypolimnas bolina $M$ & $\mathrm{~T}, \mathrm{~A}$ & Positive \\
\hline & Butterfly & Doleschalia bisaltide & $\mathrm{T}, \mathrm{A}$ & Negative \\
\hline & Butterfly & Junonia hedonia & $\mathrm{T}, \mathrm{A}$ & Negative \\
\hline & Butterfly & Euploea midamus & $\mathrm{T}, \mathrm{A}$ & Negative \\
\hline & Butterfly & Appias olferna & $\mathrm{T}, \mathrm{A}$ & Negative \\
\hline & Butterfly & Mycalesis sp. & $\mathrm{T}, \mathrm{A}$ & Positive \\
\hline & Butterfly & Acraea terpsicore & $\mathrm{T}, \mathrm{A}$ & Negative \\
\hline & Butterfly & Graphium agamemnon & $\mathrm{T}, \mathrm{A}$ & Positive \\
\hline & Butterfly & Eurema hecabe & $\mathrm{T}, \mathrm{A}$ & Negative \\
\hline \multirow[t]{2}{*}{ Odonata } & Dragonfly & Orthetrum sabina & $\mathrm{T}, \mathrm{A}$ & Negative \\
\hline & Dragonfly & Crocothemis servilia & $\mathrm{T}, \mathrm{A}$ & Negative \\
\hline \multirow[t]{8}{*}{ Orthoptera } & Grasshopper & Tenodera fasciata & $\mathrm{T}, \mathrm{A}$ & Negative \\
\hline & Grasshopper & Oxya intricata & $\mathrm{T}, \mathrm{A}$ & Negative \\
\hline & Grasshopper & Catantops humilis & $\mathrm{T}, \mathrm{A}$ & Negative \\
\hline & Grasshopper & Xiphidion maculatum & $\mathrm{T}, \mathrm{A}$ & Negative \\
\hline & Grasshopper & Euscyrtusconcinnus & $\mathrm{T}, \mathrm{A}$ & Positive \\
\hline & Grasshopper & Tagaeta marginella & $\mathrm{T}, \mathrm{A}$ & Positive \\
\hline & Grasshopper & Atractomorpha crenaticeps & $\mathrm{T}, \mathrm{A}$ & Positive \\
\hline & Grasshopper & Atractomorpha psittacina & $\mathrm{T}, \mathrm{A}$ & Negative \\
\hline Total & & 49 & & $\begin{array}{l}\text { Pos: } 22 \\
\text { Neg: } 27\end{array}$ \\
\hline
\end{tabular}

Note: Percentage of Wolbachia sp.: 22 / $49 \times 100 \%=44.9 \%$ 


\section{Discussion}

Wolbachia can spread rapidly among host populations through vertical lineages (vertical transmission from parent to offspring). The presence of Wolbachia has an impact on host life and ecology. These include reproductive manipulation. Reproductive manipulations include feminization (male acquires female traits); induction of parthenogenesis (female offspring are produced without fertilization), male embryo killing, and cytoplasmic incompatibility (CI), where sperm from infected males cannot produce viable offspring with females that do not harbor the same bacterial strain (Werren et al. 2008). Therefore, the four strategies mentioned above could enhance the survival and spread of the bacteria in insect populations as the host, even at the expense of host fitness.

From the 49 samples of insects, fragments were appeared in 22 samples using $81 \mathrm{~F}$ and $691 \mathrm{R}$ primers for amplification. The 610 bp fragments were almost similar for all positive samples. It indicates the presence of Wolbachia in the sample. The $81 \mathrm{~F}$ and $691 \mathrm{R}$ primers were targeting the wsp. Wolbachia surface protein (WSP) contains the transmembrane domain and standard signal peptide for secretion. It was one of the most abundantly expressed proteins in the arthropod endosymbiont and shows homologies to the major outer membrane proteins of Ehrlichia spp. and related genera. It proves that wsp gene can be very useful for phylogenetic studies of arthropod Wolbachia because it expresses WSP as a membrane protein of the bacterial outer envelope (Bazzochi et al. 2000). For internal control, a primer which amplifies $28 \mathrm{~S}$ fragment were also included. $28 \mathrm{~S}$ ribosomal RNA is the structural ribosomal RNA (rRNA) for the large component of eukaryotic cytoplasmic ribosomes, and thus one of the basic components of all eukaryotic cells. The fragment from the positive samples revealed similar results to the fragments from wMel+ mosquito for positive controls. It indicates that Wolbachia in wMel+ mosquito has similarity, based on $81 \mathrm{~F}$ and $691 \mathrm{R}$ primers amplification, to the Wolbachia in most of the wild insects in this study.

Twelve out of 23 butterfly species (Lepidoptera) were positive for Wolbachia. The presence of Wolbachia in butterfly species was also reported from Western Ghats, India. Twenty-nine species representing five families (Papilionidae, Nymphalidae, Pieridae, Lycaenidae, Hesperiidae) were positive for Wolbachia (Salunke et al. 2012). The family Papilionidae, represented by Papilio demoleus, showed different results to this study. $P$. demoleus from the Western Ghats were positive for Wolbachia, but the Yogyakarta sample showed a negative result. Other species such as Hypolimnas bolina $M$ and Neptis hylas showed a similar result. In this study, some species from Hymenoptera, including bees and wasps, are positive for Wolbachia. Hyposoter horticola, a parasitoid of the Glanville fritillary butterfly in the Åland Islands in Finland, was also infected by three Wolbachia pipientis strains, i.e. wHho, wHho2, and wHho3 (Duplouy et al. 2015). Wolbachia was also reported in Diprionpini (L.) and Neodiprion sertifer (Hymenoptera) from Northern Italy. The presence of Wolbachia in wasps can be diverse among species. Maternal vertical inheritance is considered the primary route of Wolbachia transmission from one host generation to another. Another mechanism, horizontal transmission, has been reported in wasps of the genus Trichogramma, and the parasitoid Nasonia wasp, which allows Wolbachia to infect several host species and contributes to its vast host range. The horizontal transmission allows Wolbachia to infect several host species and contributes to its immense host range (Pistone et al. 2014).

In this study, 2 out of 5 species of the order Coleoptera were positive for Wolbachia. A study by Sontowski et al. (2015) revealed the presence of Wolbachia in seven families of Coleoptera (Buprestidae, Hydraenidae, Dytiscidae, Hydrophilidae, Gyrinidae, Haliplidae, and Noteridae) from Europe with an infection rate of $31 \%$ in total. The infection rates for each family was ranging from $14 \%$ to $63 \%$ for families with more than 12 sampled species. There has not been much study on screening for Wolbachia infection in beetles (Clark et al. 2001; Weinert et al. 2007), indicating that Wolbachia infections in beetles are generally lower compared to other insects orders. The negative result of Wolbachia infection also appeared in three species of the order Odonata. This result is different from the study by Salunkhe et al. (2015) that found fifteen species of Odonate representing five families from Central India are positive for Wolbachia with an infection rate of $70 \%$ (Salunkhe et al. 2015). The prevalence of Wolbachia infection varies from $100 \%$ to extremely low between host species and among populations within a host species. This variation of prevalence arises because of the host-symbiont associations due to different environmental conditions, different stages of infection history, or affected by variable genetic factors of either the symbiont or the host (Salunkhe et al. 2015). Due to manipulating its host reproductive system so that Wolbachia can survive in their host population despite the apparent costs of host fecundity. Cytoplasmic incompatibility (CI) inducing-Wolbachia causes total or partial reproductive failure between males and females with different infection statuses. It provides a reproductive advantage to female hosts, which can produce viable offspring regardless of whether they mate with infected or uninfected males (Salunkhe et al. 2015). Wolbachia distorts the population sex ratio by male-killing, parthenogenesis, and feminization. It promotes the production and fitness of infected females, ensuring the transmission of infection through generations. The coexistence of infected and uninfected individuals in a population occurs if there is a perfect vertical transmission of the symbiont (Duplouy et al. 2015).

Two species of the order Diptera in this study showed positive results for Wolbachia. Wolbachia infected at least 19 species of fruit flies of the genus Drosophila (Glasser and Meola, 2010). In some species, Wolbachia causes robust and intricate patterns of cytoplasmic incompatibility, such as Drosophila simulans. In contrast, in other species, reproductive phenotypes are generally weak or absent, such as D. melanogaster. Despite the lack of a robust reproductive phenotype, Wolbachia infection in $D$. melanogaster is widely spread. The mosquito species Aedes albopictus also showed a positive result for 
Wolbachia. Another study by Ahmad et al. (2017) at eight study sites in five states (Malacca, Selangor, Terengganu, Perak, and Pahang) in Malaysia showed a high percentage of Wolbachia infection with $98.6 \%$ in females and $95.1 \%$ in males.

The insects in this study were collected from two areas with almost similar characters, i.e., local residential areas. The high rate of infection in the field $(44,9 \%)$ indicates that Wolbachia thrives in open or less industrialized areas, such as residential areas, parks, and schools, which have a much higher infection rate. The infected species show similar preference patterns of food and the environment. The majority of infected species feed on decaying matter and prefer humid environments (Jeong et al. 2012). The presence of Wolbachia in insects in this study were widely varied among species. Age and ecology of the host, including geographical and seasonal variations, are responsible for the variation of infection rate in the natural insect population (Sarwar et al. 2017).

The Wolbachia surface protein (WSP) is commonly used as a marker for strain typing, and a strain typing system utilizing wsp gene has been developed. The wsp gene is analogous to the antigens employed for serotyping pathogenic bacteria. It is approximately ten times more variable in its DNA sequence than $16 \mathrm{~S}$ rRNA (Zhou et al. 1998). The wsp gene can be detected similarly in both thorax and abdomen, and also the whole body of insect samples, indicating that Wolbachia was distributed equally in the whole body of insects. Wolbachia is distributed in the somatic and reproductive tissues of the mosquito, where transmissible pathogens reside and replicate (Zouache et al. 2009). The highest density of bacteria was found in the future oocyte, confirming a common feature of Wolbachia, which is to transfer from nurse cells into the oocyte through cytoplasmic dumping as in Drosophila (Ferree et al. 2005).

This study supports other findings of the ubiquity of Wolbachia in nearly $30-70 \%$ of the world's insect species, including flies, bees, butterflies, and mosquitoes in the different regions in the world. Considering the wide distribution of Wolbachia as a natural endosymbiont, artificially infecting Wolbachia to Aedes aegypti is a safe alternative method to control dengue transmission. Since public attention is focused on safety, this outcome may answer one of these crucial issues.

\section{ACKNOWLEDGEMENTS}

This study was funded by the Tahija Foundation and is part of the World Mosquito Program, Yogyakarta, Indonesia.

\section{REFERENCES}

Ahmad NA, Vythilingam I, Lim YA, Zabari NZAM, Lee HL. 2017. Detection of Wolbachia in Aedes albopictus and their effects on chikungunya virus. Am J Trop Med Hyg 96 (1): 148-156. DOI: 10.4269/ajtmh.16-0516.
Bandi C, Dunn AM, Hurst GD, Rigaud T. 2001. Inherited microorganisms, sex-specific virulence and reproductive parasitism. Trends Parasitol 17(2): 88-94. DOI: 10.1016/s1471-4922(00)01812-2.

Bazzocchi C, Ceciliani F, McCall JW, Ricci I, Genchi C, Bandi C. 2000. Antigenic role of the endosymbionts of filarial nematodes: IgG response against the Wolbachia surface protein in cats infected with Dirofilaria immitis. Proc R Soc Lond B 267 (1461): 2511-2516. DOI: 10.1098/rspb.2000.1313.

Bhatt S, Gething PW, Brady OJ, Messina JP, Farlow AW, Moyes CL. 2013. The global distribution and burden of dengue. Nature 496 (7446): 504. DOI: 10.1038/nature12060.

Bouchon D, Rigaud T, Juchault P. 1998. Evidence for widespread Wolbachia infection in isopod crustaceans: molecular identification and host feminization. P Roy Soc B-Biol Sci 265(1401): 1081-1090. DOI: 10.1098/rspb.1998.0402.

Braig HR, Zhou W, Dobson SL, O’Neill SL. 1998. Cloning and characterization of a gene encoding the major surface protein of the bacterial endosymbiont Wolbachia pipientis. J Bacteriol 180 (9): 2373-2378. DOI: 10.1128/jb.177.8.2041-2049.1995.

Breeuwer J, Jacobs G. 1996. Wolbachia: intracellular manipulators of mite reproduction. Exp Appl Acarol 20 (8): 421-34. DOI: 10.1007/bf00053306.

Clark TL, Meinke LJ, Skoda SR, Foster JE. 2001. Occurrence of Wolbachia in selected Diabroticite (Coleoptera: Chrysomelidae) beetles. Ann Entomol Soc Am 94 (6): 877-885. DOI: 10.1603/00138746(2001)094[0877: oowisd]2.0.co;2.

Duplouy A, Couchoux C, Hanski I, van Nouhuys S. 2015. Wolbachia infection in a natural parasitoid wasp population. PLoS One 10 (8): e0134843. DOI: 10.1371/journal.pone.0134843.

Ferree PM, Frydman HM, Li JM, Cao J, Wieschaus E, Sullivan W. 2005. Wolbachia utilizes host microtubules and dynein for anterior localization in the Drosophila oocyte. PLoS Pathog. 1 (2): e14. DOI: 10.1371/journal.ppat.0010014.

Glasser RL, Meola MA. 2010. The native Wolbachia endosymbionts of Drosophila melanogaster and Culex quinquefasciatus increase host resistance to West Nile virus infection. PLoS One. 5 (8): e11977. DOI: 10.1371/journal.pone.0011977.

Indriani C, Ahmad RA, Wiratama BS, Arguni E, Supriyati E, Sasmono RT, et al. 2018. Baseline characterization of dengue epidemiology in Yogyakarta City, Indonesia, before a randomized controlled trial of Wolbachia for arboviral disease control. Am J Trop Med Hyg 99 (5): 1299-307. DOI: 10.4269/ajtmh.18-0315.

Jeong G, Ahn J, Jang Y, Choe JC, Choi H. 2012. Wolbachia infection in the Loxoblemmus complex (Orthoptera: Gryllidae) in Korea. J AsiaPac Entomol 15 (4): 563-566. DOI: 10.1016/j.aspen.2012.07.002.

Jeyaprakash A, Hoy M. Long. 2000. PCR improves Wolbachia DNA amplification: wsp sequences found in $76 \%$ of sixty-three arthropod species. Insect Mol Biol 9 (4): 393-405. DOI: 10.1046/j.13652583.2000.00203.x

Kementrian Kesehatan RI. 2010. Demam berdarah dengue di Indonesia 1968-2009. Buletin Jendela Epidemiologi Pusat Data dan Surveilans Epidemiologi Kementrian Kesehatan RI, Jakarta. [Indonesian]

Lohman DJ, Peggie D, Pierce NE, Meier R. 2008. Phylogeography and genetic diversity of a widespread Old World butterfly, Lampides boeticus (Lepidoptera: Lycaenidae). BMC Evol Biol 8 (1): 301. DOI: 10.1186/1471-2148-8-301.

Narita S, Nomura M, Kato Y, Yata O, Kageyama D. 2007. Molecular phylogeography of two sibling species of Eurema butterflies. Genetica 131 (3): 241-253. DOI: 10.1007/s10709-006-9134-1.

Pfarr K, Foster J, Slatko B, Hoerauf A, Eisen JA. 2007. On the taxonomic status of the intracellular bacterium Wolbachia pipientis: should this species name include the intracellular bacteria of filarial nematodes? Int J Syst Evol Micr 57 (Pt 8): 1677. DOI: 10.1099/ijs.0.65248-0.

Pistone D, Bione A, Epis S, Pajoro M, Gaiarsa S, Bandi C. 2014. Presence of Wolbachia in three Hymenopteran species: Diprion pini (Hymenoptera: Diprionidae), Neodiprion sertifer (Hymenoptera: Diprionidae), and Dahlbominus fuscipennis (Hymenoptera: Eulophidae). J Insect Sci 14 (1): 147. DOI: 10.1093/jisesa/ieu009.

Rasgon JL, Scott TW. 2004. Phylogenetic characterization of Wolbachia symbionts infecting Cimex lectularius L. and Oeciacus vicarius Horvath (Hemiptera: Cimicidae). J Med Entomol 41 (6): 1175-8. DOI: 10.1603/0022-2585-41.6.1175.

Rowley SM, Raven RJ, McGraw EA. 2004. Wolbachia pipientis in Australian spiders. Curr Microbiol 49 (3): 208-214. DOI: 10.1007/s00284-004-4346-z. 
Ruang-Areerate T, Kittayapong P. 2006. Wolbachia transinfection in Aedes aegypti: a potential gene driver of dengue vectors. Proc Natl Acad Sci USA 103 (33): 12534-12539. DOI: 10.1073/pnas.0508879103.

Salunke BK, Salunkhe RC, Dhotre DP, Walujkar SA, Khandagale AB, Chaudhari R. 2012. Determination of Wolbachia diversity in butterflies from Western Ghats, India, by a multigene approach. Appl Environ Microbiol 78 (12): 4458-4467. DOI: 10.1128/aem.07298-11.

Salunkhe RC, Dhotre DP, Salunke BK, Patil VS, Mahale V, Andrew RJ 2015. Distribution and molecular characterization of Wolbachia endosymbionts in Odonata (Insecta) from Central India by multigene approach. Curr Sci 108 (5): 971-978.

Sarwar MS, Jahan N, Batool F, Kalim B. 2017. Wsp gene-based detection and characterization of Wolbachia in indigenous Drosophila. J Biol Env Sci 10 (4): 142-149.

Sontowski R, Bernhard D, Bleidorn C, Schlegel M, Gerth M. 2015. Wolbachia distribution in selected beetle taxa characterized by PCR screens and MLST data. Eco Evol 5 (19): 4345-4353. DOI: 10.1002/ece3.1641.

Stevens L, Giordano R, Fialho RF. 2001. Male-killing, nematode infections, bacteriophage infection, and virulence of cytoplasmic bacteria in the genus Wolbachia. Ann Rev Ecol Syst 32 (1): 519-545. DOI: 10.1146/annurev.ecolsys.32.081501.114132.

Taylor M, Hoerauf A. 1999. Wolbachia bacteria of filarial nematodes. Parasitol Today 15 (11): 437-442.

Tsai K-H, Lien J-C, Huang C-G, Wu W-J, Chen W-J. 2004. Molecular (sub) grouping of endosymbiont Wolbachia infection among mosquitoes of Taiwan. J Med Entomol 41 (4): 677-683. DOI: 10.1603/0022-2585-41.4.677.
Weinert LA, Tinsley MC, Temperley M, Jiggins FM. 2007. Are we underestimating the diversity and incidence of insect bacterial symbionts? A case study in ladybird beetles. Biol Lett 3 (6): 678-681. DOI: $10.1098 / \mathrm{rsbl} .2007 .0373$.

Werren JH, Zhang W, Guo LR. 1995. Evolution and phylogeny of Wolbachia: reproductive parasites of arthropods. Proc Biol Sci 261(1360): 55-63. DOI: 10.1098/rspb.1995.0117.

Werren JH, Windsor DM. 2000. Wolbachia infection frequencies in insects: evidence of a global equilibrium? Proc Biol Sci 267 (1450): 1277-1285. DOI: 10.1098/rspb.2000.1139.

Werren JH, Baldo L, Clark ME. 2008. Wolbachia: master manipulators of invertebrate biology. Nat Rev Microbiol 6 (10): 741-751. DOI: 10.1038/nrmicro1969.

Wenseleers T, Ito F, Van Borm S, Huybrechts R, Volckaert F, Billen J. 1998. Widespread occurrence of the microorganism Wolbachia in ants. Proc Biol Sci 265 (1404): 1447-1452. DOI: 10.1098/rspb.1998.0456.

Woo Oh H, Gwang Kim M, Woon Shin S, Sook Bae K, Joon Ahn Y, Park HY. 2000. Ultrastructural and molecular identification of a Wolbachia endosymbiont in a spider, Nephila clavata. Insect Mol Biol 9 (5): 539-543. DOI: 10.1046/j.1365-2583.2000.00218.x.

Zhou W, Rousset F, O'Neill S. 1998. Phylogeny and PCR-based classification of Wolbachia strains using wsp gene sequences. Proc Biol Sci 265 (1395): 509-515. DOI: 10.1098/rspb.1998.0324.

Zouache K, Voronin D, Tran-Van V, Mousson L, Failloux A-B, Mavingui P. 2009. Persistent Wolbachia and cultivable bacteria infection in the reproductive and somatic tissues of the mosquito vector Aedes $\begin{array}{lllll}\text { albopictus. PLoS One } 4 \text { (7): e6388. DOI: } & \end{array}$ 10.1371/journal.pone.0006388. 